\title{
Effect of Zr Microalloying on the Microstructures and Strengthening Mechanism of As-Cast Al-Fe-Zr Alloys
}

\author{
Jieyun Ye ${ }^{1}$, Renguo Guan ${ }^{1,2}{ }^{2}$, Hongjin Zhao ${ }^{1}$, Changwei He ${ }^{1}$ and Kezhi Xiong ${ }^{1}$ \\ 1 Faculty of Material Metallurgy and Chemistry, Jiangxi University of Science and Technology, \\ Ganzhou 341000, China; 9120130116@jxust.edu.cn (J.Y.); 9119960101@jxust.edu.cn (H.Z.); \\ 1320181650@mail.jxust.edu.cn (C.H.); 1320181654@mail.jxust.edu.cn (K.X.) \\ 2 Engineering Research Center of Continuous Extrusion, Dalian Jiaotong University, Ministry of Education, \\ Dalian 116028, China \\ * Correspondence: 7120190023@mail.jxust.edu.cn; Tel.: +86-151-7908-9086
}

Received: 17 September 2020; Accepted: 21 October 2020; Published: 23 October 2020

check for updates

\begin{abstract}
The microstructure and mechanical properties of Al-0.35Fe alloys with a series of different zirconium ( $\mathrm{Zr}$ ) additions from 0.1 to $0.4 \%$ are investigated by optical microscopy, scanning electron microscopy, transmission electron microscopy and tensile testing. The as-cast structure of the alloys varies with the $\mathrm{Zr}$ content. When the content of $\mathrm{Zr}$ is $0.1 \%$, $\mathrm{Zr}$ dissolves into the aluminum (Al) matrix completely and iron $(\mathrm{Fe})$ concentrates along the boundary in a network of eutectic $\mathrm{Al}_{3} \mathrm{Fe}$. With the increase in $\mathrm{Zr}$ content to $0.2 \%$ and above, nanoscale $\mathrm{Al}_{3} \mathrm{Zr}$ particles appear in the alloy. With the $\mathrm{Zr}$ content increasing from 0.1 to $0.4 \%$, the grain size of the Al matrix decreases from 73 to $23 \mu \mathrm{m}$. The morphology of the eutectic $\mathrm{Al}_{3} \mathrm{Fe}$ phase changes from short rod-like to an agglomerated structure consisting of finer and shorter rod-like shapes. The tensile and yield strengths increase while the total elongation decreases with increasing $\mathrm{Zr}$ content. The strengthening mechanism of the alloy can be attributed to the combination of fine-grain, solution and second-phase strengthening.
\end{abstract}

Keywords: Al-Fe-Zr alloys; microalloying; microstructure; mechanical properties

\section{Introduction}

Fe is considered to be one of the most harmful impurities in Al alloys. Because of its low solubility in $\mathrm{Al}$ alloys, Fe often precipitates in the form of a needle-like $\beta$-Fe phase during solidification [1-5]. The $\beta$-Fe phase distributes at grain boundaries and can easily cause stress concentration. Eventually, it leads to a decrease in strength and toughness [6,7]. However, the removing process for Fe impurities is difficult and expensive. Considering the good heat resistance and high hardness of the Fe-rich phase, more and more research has become focused on the modification of the Fe-rich phase in recent years [8-10]. Wang et al. [11] refined $\mathrm{Al}_{3} \mathrm{Fe}$ to the nanoscale through shear deformation by means of rheo-extrusion, thereby improving the mechanical properties of an Al-1Fe alloy. Stolyrov et al. [12] significantly refined $\mathrm{Al}_{3} \mathrm{Fe}$ by equal-channel angular pressing and the tensile strength and elongation increased as a result. Li et al. [13] found that with an increase in the magnetic field, the nuclei number of the primary $\mathrm{Al}_{3} \mathrm{Fe}$ increased, resulting in a decrease in the $\mathrm{Al}_{3} \mathrm{Fe}$ phase. The addition of alloy elements has also been studied to improve the Fe-rich phase.

Rahul et al. [14] found that the addition of cobalt to Al-Fe alloys could hinder the diffusion behaviors of Fe and inhibit the growth of the $\mathrm{Al}_{3} \mathrm{Fe}$ phase. Zhang et al. [15] demonstrated that the addition of scandium significantly refined $\mathrm{Al}_{3} \mathrm{Fe}$ to the nanoscale. Shi et al. [8] indicated that adding $0.3 \%$ (all compositions quoted in this work are in wt.\% unless specified otherwise) of rare-earth elements into an as-cast Al-1Fe alloy could improve the morphology of the Fe-rich phase and transform it from needle flakes to short rod shapes. $\mathrm{Zr}$ is a perfect addition to Al alloys, since it can form a 
dispersive and fine precipitated phase which is coherent with the matrix. Combined microalloying is often designed in $\mathrm{Al}$ alloys through $\mathrm{Sc}, \mathrm{Er}, \mathrm{Zr}$ addition. Wang et al. [16] and Deng et al. [17] suggested that the formation of $\mathrm{Al}_{3}(\mathrm{Sc}, \mathrm{Zr})$ prevents the unsuitable diffusion and promotes the heterogeneous nucleation for $\alpha-\mathrm{Al}$ during solidification. The recrystallization behavior of $\mathrm{Al}-3 \mathrm{Cu}(\mathrm{wt} . \%)$ at $500{ }^{\circ} \mathrm{C}$ was fully inhibited with co-additions of $\mathrm{Er}$ and $\mathrm{Zr}$ and leading to a significant grain refinement [18]. Besides, the $\mathrm{Zr}$ tends to segregate to $\theta^{\prime}$ interfaces and grain boundaries, which improves $\theta^{\prime}$ stability and induces precipitation of particles $\left(\mathrm{Al}_{3}(\mathrm{Sc}, \mathrm{Zr})\right)$ at grain boundary $[19,20]$. Hence, the strength, creep resistance and low-stress corrosion can be improved by $\mathrm{Zr}$ microalloying. As for Al-Fe alloy after hot-extrusion, the addition of $\mathrm{Zr}$ also inhibits recrystallization and improves the heat resistance [21]. However, the effect of $\mathrm{Zr}$ microalloying on Al-Fe alloys during solidification has not been studied.

At present, for a large amount of aluminum alloy resource recovery, the recovery cost increases due to the high Fe content. How to make full use of Al-Fe alloy is a difficult problem and challenge [22,23]. So this research focuses mainly on the effect of $\mathrm{Zr}$ microalloying on the improvement of Fe phase morphology, mechanical properties and strengthening mechanism. Al-Fe-Zr alloys with a series of different $\mathrm{Zr}$ additions from 0.1 to $0.4 \%$ are prepared using a copper mold. The microstructure is investigated and the room temperature compressive properties are assessed. Furthermore, the work is extended to understanding the grain refining mechanism, the modification mechanism of the Fe-rich phase and the strengthening mechanism of $\mathrm{Zr}$ microalloying $\mathrm{Al}-0.35 \mathrm{Fe}$ alloys.

\section{Materials and Methods}

Al-0.35Fe alloys with a series of $\mathrm{Zr}$ additions from 0.1 to $0.4 \%$ were prepared using commercial pure aluminum (99.99\%), with master alloys of $\mathrm{Al}-10 \mathrm{Zr}$ and $\mathrm{Al}-10 \mathrm{Fe}$ (mass fraction, \%). For each composition, pure $\mathrm{Al}$ was melted in a crucible resistance furnace under the protection of argon gas. Subsequently, various amounts of master alloys were added into the melt and maintained for several minutes. A preheated ceramic rod was utilized to stir the melt in order to homogenize Fe and $\mathrm{Zr}$. After degassing and deslagging, the molten alloy was poured into a preheated metal mold with a size of $\Phi 40 \times 130 \mathrm{~mm}$. The alloy composition was measured by an Iris Advantage 1000 inductively-coupled plasma spectrometer (Thermo Jarrel Ash Corporation, Franklin, MA, USA), as shown in Table 1 [21].

Table 1. Actual compositions of the four Al-Fe-Zr alloys (wt.\%).

\begin{tabular}{cccc}
\hline Samples & Fe & Zr & Al \\
\hline Al-0.35Fe-0.1Zr & 0.352 & 0.122 & Bal. \\
Al-0.35Fe-0.2Zr & 0.341 & 0.247 & Bal. \\
Al-0.35Fe-0.3Zr & 0.357 & 0.298 & Bal. \\
Al-0.35Fe-0.4Zr & 0.354 & 0.380 & Bal. \\
\hline
\end{tabular}

The samples for microstructural observation were prepared in specimens with dimensions of $\Phi 10 \times 10 \mathrm{~mm}$, extracted from the central part of the casting ingots. The sample surfaces were polished and etched by a Keller alcohol solution for observation. The microstructures were examined using a metallurgical DSX500 microscope (OLYMPUS, Tokyo, Japan), and the grain size distribution was statistically measured by analysis software (IMAGE-PRO-PLUS 6.0) according to the ASTM E112-2013 standard. The morphology and distribution of the phase were investigated through the combination of an Ultra Plus scanning electron microscope (Carl Zeiss AG, Oberkochen, Germany) equipped with X-ray energy dispersive spectrometers. A FEI G2 20 transmission electron microscope (FEI Company, Hillsboro, OR, USA) was used to investigate the precipitates, grain boundaries and other substructures. Thin foils for the transmission electron microscopy analysis were prepared by electrospark wire electrode cutting sample pieces from the extruded materials and polishing them mechanically to $\sim 50 \mu \mathrm{m}$. Discs with a $3 \mathrm{~mm}$ diameter were punched and dimpled to $60 \mu \mathrm{m}$, followed by twin-jet electropolishing (Struers ApS, Ballerup, Denmark) at $20 \mathrm{~V}$. A solution of one third (volume fraction) nitric acid and two-thirds methanol at $-25^{\circ} \mathrm{C}$ was applied during electropolishing. 
Tensile testing of the alloy ingots was carried out using a CMT5105 electronic tensile testing machine (MTS Test Technology Co. Ltd, Jinan, China) at a tensile velocity of $2 \mathrm{~mm} / \mathrm{min}$. Round tensile specimens were prepared according to the GB/T 228.1-2010 standard and with the gage length of $25 \mathrm{~mm}$, which were cut out by electric discharge machining. An electronic extensometer was used to record a load-deformation curve within the gauge distance automatically and then the yield strength was calculated on the basis of the load-deformation curve. Tensile properties were tested at room temperature, and to ensure the accuracy of the test data, tensile samples for each $\mathrm{Zr}$ additions were tested 3 times.

\section{Results}

\subsection{Effect of Zr Content on As-Cast Microstructures and Phase Composition}

Figure 1 shows the optical microstructure map of the as-cast Al-Fe-Zr alloy, etched using Keller's reagent. The as-cast microstructure of $\mathrm{Al}-0.35 \mathrm{Fe}-0.1 \mathrm{Zr}$ alloy had an irregular bulky shape and formed a rough dendritic structure. The average size of the $\alpha$-Al grains was $76 \pm 5 \mu \mathrm{m}$. However, the addition of $0.2 \% \mathrm{Zr}$ resulted in better modification effects in $\mathrm{Al}-0.35 \mathrm{Fe}-0.2 \mathrm{Zr}$ alloy (Figure $1 \mathrm{~b}$ ) and the average size of the $\alpha$-Al grains decreased to $35 \pm 4 \mu \mathrm{m}$. When the content of $\mathrm{Zr}$ increased to 0.3 and $0.4 \%$, the average grain sizes were $27 \pm 3 \mu \mathrm{m}$ and $23 \pm 2 \mu \mathrm{m}$, respectively (Figure 1c,d). Figure 1e shows the average grain size of the as-cast microstructure. With the increase in $\mathrm{Zr}$ content, the average grain size of the alloy decreases gradually. From the standard deviation results (Figure 1e), the grain size becomes more uniform when the $\mathrm{Zr}$ content increases to $0.3 \%$ and $0.4 \%$, and the growth morphology of $\alpha$-Al changed from dendritic to fine equiaxial crystals. In conclusion, the as-cast microstructures were efficiently refined by the addition of $\mathrm{Zr}$ from 0.1 to $0.4 \%$. The cast morphology was optimized significantly. It is worth mentioning that when the $\mathrm{Zr}$ content was increased from 0.1 to $0.2 \%$, the refining effect was obvious. However, the refining effect change was not obvious when the $\mathrm{Zr}$ content was further increased.

The scanning electron microscopy and energy-dispersive X-ray spectroscopy (EDS) results are shown in Figure 2. Al- $0.35 \mathrm{Fe}-0.1 \mathrm{Zr}$ alloy is composed of $\alpha-\mathrm{Al}$ matrix and a brighter-hued white second phase distributed at the grain boundaries. The average length of the second phase (red arrow) is $300 \mathrm{~nm}$. The EDS analysis shows that the second phase is composed of $\mathrm{Fe}$ and $\mathrm{Al}$ (Figure 2e). In $\mathrm{Al}-0.35 \mathrm{Fe}-0.2 \mathrm{Zr}$ alloy, the elements of the second phase distributed at the grain boundaries are $\mathrm{Al}$, Fe and Zr. The morphology of the second phase changes to granulate and it shows discontinuity. After magnification, it is found that the particles are actually spherical clusters composed of a large number of small and short rod-shaped phases. The average size of the spherical clusters is $1.2 \mu \mathrm{m}$ and the short rod-shaped phases are $190 \mathrm{~nm}$. When $\mathrm{Zr}$ content increased to 0.3 and $0.4 \%$, spherical clusters become more evenly distributed.

Figure 3 shows the TEM micrograph of $\mathrm{Al}-0.35 \mathrm{Fe}-0.1 \mathrm{Zr}$ alloy and $\mathrm{Al}-0.35 \mathrm{Fe}-0.2 \mathrm{Zr}$ alloy. It can be seen that the rod-shaped phase in $\mathrm{Al}-0.35 \mathrm{Fe}-0.1 \mathrm{Zr}$ alloy and spherical cluster phase in $\mathrm{Al}-0.35 \mathrm{Fe}-0.2 \mathrm{Zr}$ alloy are $\mathrm{Al}_{3} \mathrm{Fe}$, with diffraction patterns shown in Figure $3 \mathrm{~b}$,d, respectively. The results are consistent with the research of Wang, who found that a eutectic Fe-rich phase with a short rod shape is formed during rapid solidification and it is considered as an $\mathrm{Al}_{3} \mathrm{Fe}$ phase [24]. In addition, typical butterfly-like $\mathrm{Al}_{3} \mathrm{Zr}$ precipitation was also found along grain boundary in $\mathrm{Al}-0.35 \mathrm{Fe}-0.2 \mathrm{Zr}$ alloy. 

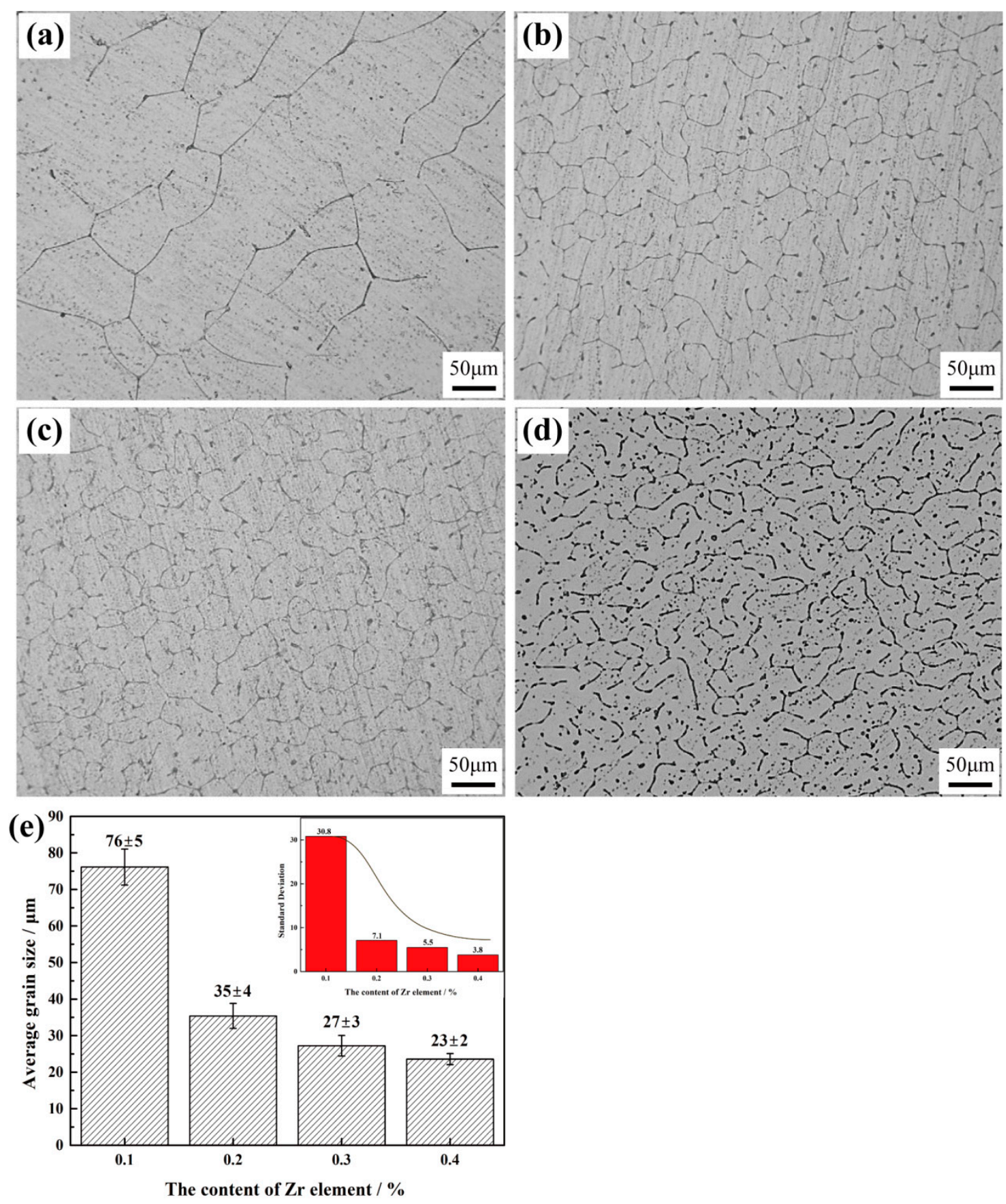

Figure 1. Optical microscopy images of as-cast alloys: (a) $\mathrm{Al}-0.35 \mathrm{Fe}-0.1 \mathrm{Zr}$; (b) $\mathrm{Al}-0.35 \mathrm{Fe}-0.2 \mathrm{Zr}$; (c) $\mathrm{Al}-0.35 \mathrm{Fe}-0.3 \mathrm{Zr}$; (d) $\mathrm{Al}-0.35 \mathrm{Fe}-0.4 \mathrm{Zr}$; (e) the average grain size and standard deviation of alloys. 

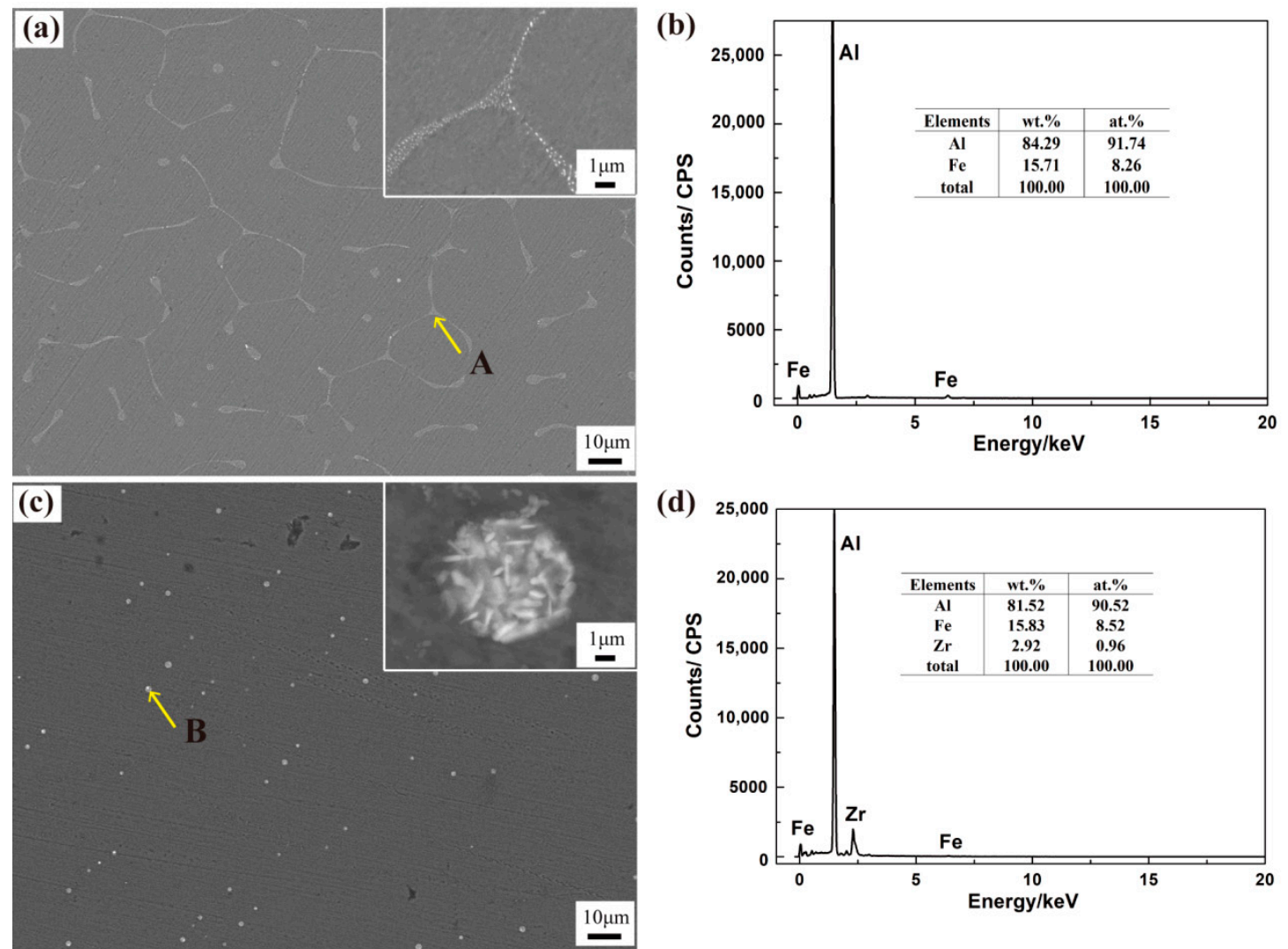

(e)

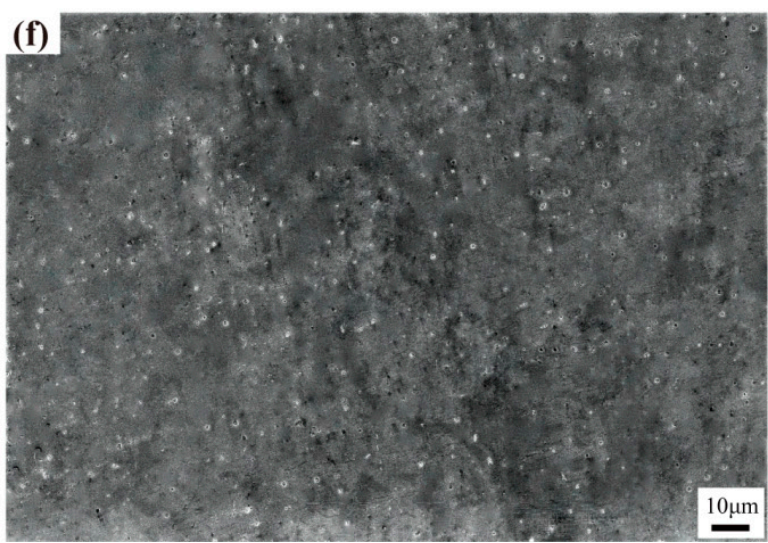

Figure 2. Scanning electron microscope images and energy-dispersive X-ray spectroscopy (EDS) of as-cast alloys: (a) Al-0.35Fe-0.1Zr alloy; (b) EDS of the A points; (c) Al-0.35Fe-0.2Zr alloy; (d) EDS of the B points; (e) Al-0.35Fe-0.3Zr alloy; (f) Al-0.35Fe-0.4Zr alloy. 

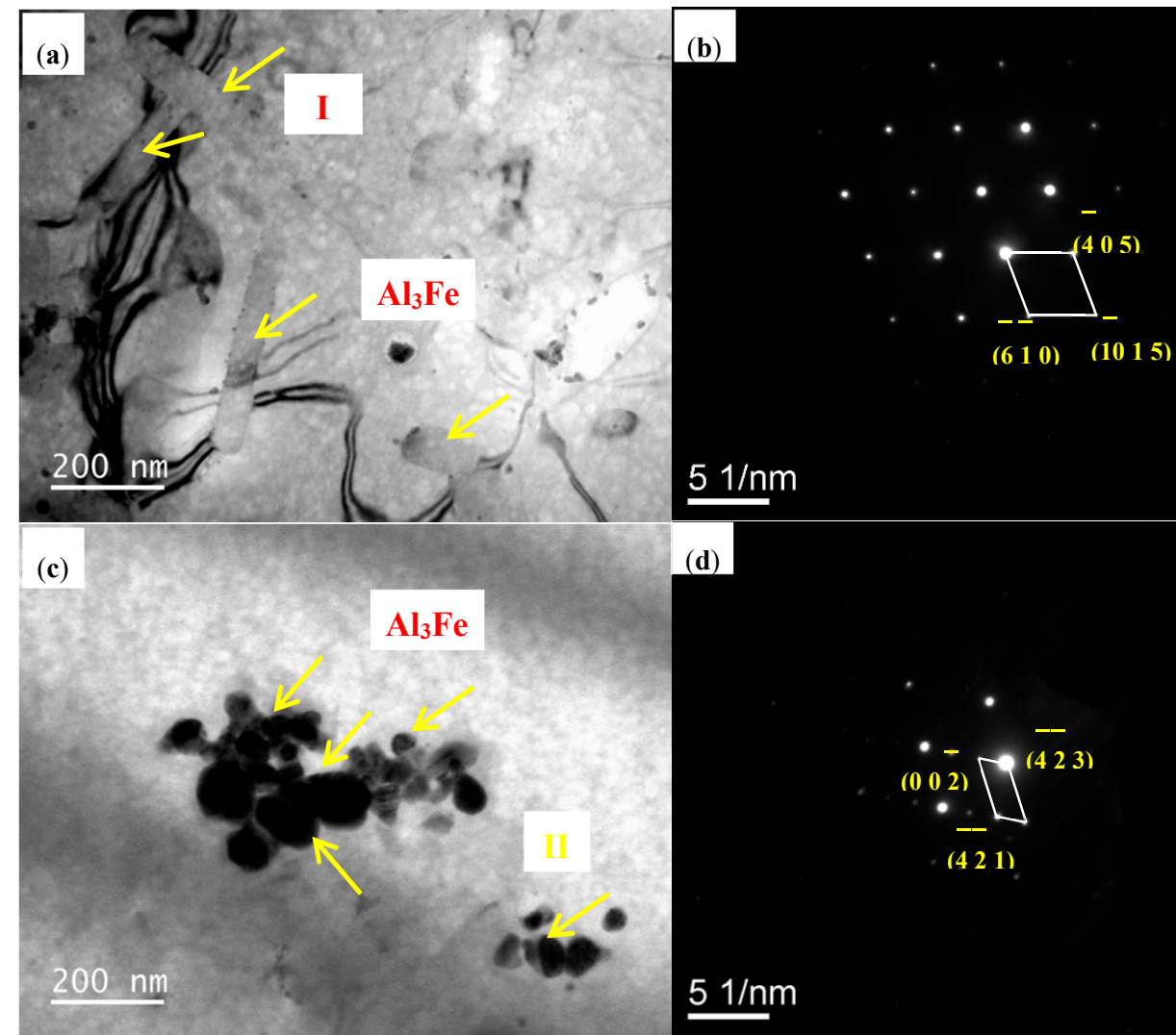

\section{$51 / \mathrm{nm}$}

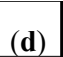

(d)
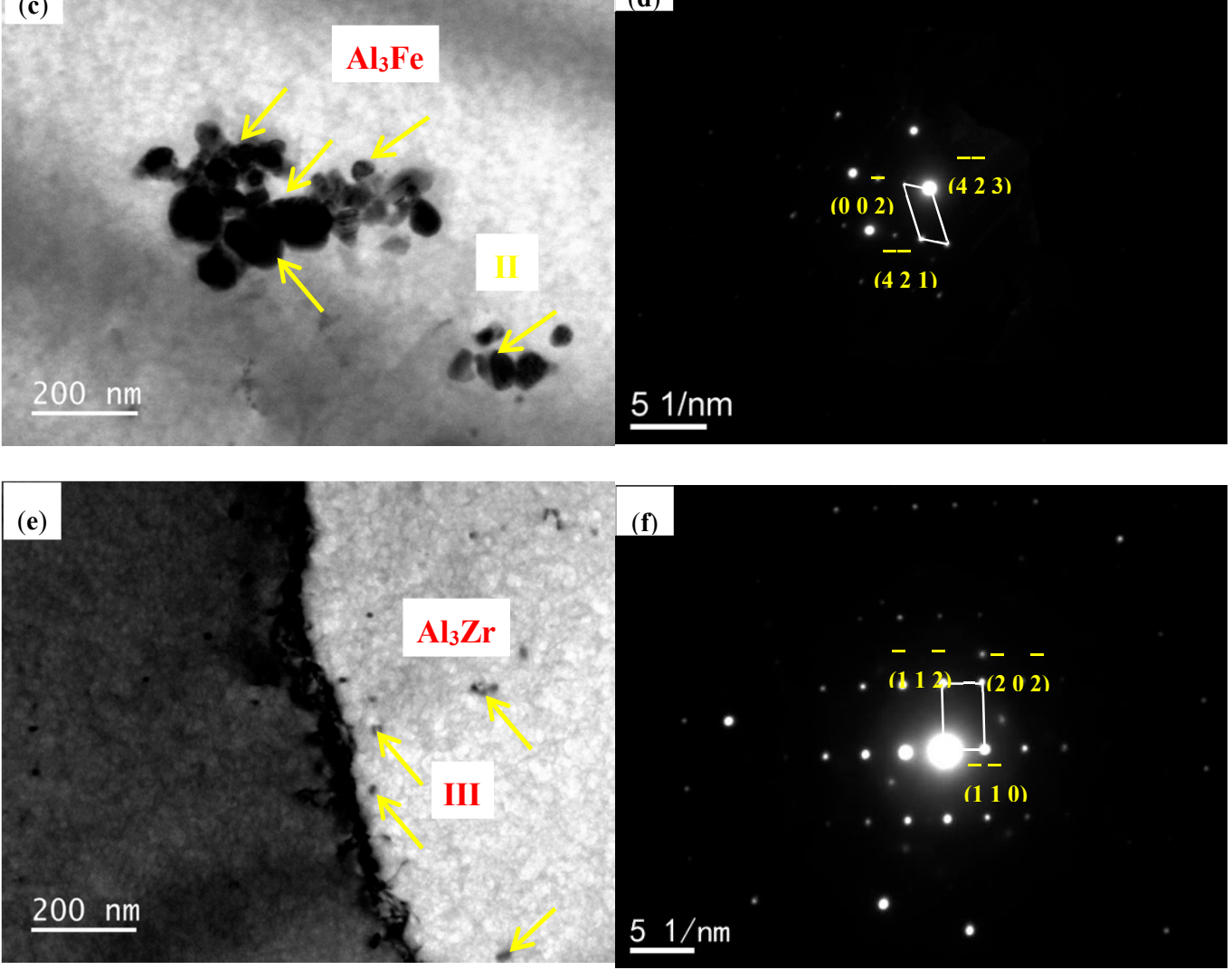

Figure 3. Transmission electron microscopy images and of as-cast alloys: (a) Al-0.35Fe-0.1Zr alloy; (b) EDS analysis of point I, showing the diffraction pattern of $\mathrm{Al}_{3} \mathrm{Fe}$ phase; (c) $\mathrm{Al}-0.35 \mathrm{Fe}-0.2 \mathrm{Zr}$ alloy; (d) EDS analysis of point II, showing the diffraction pattern of $\mathrm{Al}_{3} \mathrm{Fe}$ phase; (e) $\mathrm{Al}-0.35 \mathrm{Fe}-0.2 \mathrm{Zr}$ alloy; (f) EDS analysis of point III, showing the diffraction pattern of $\mathrm{Al}_{3} \mathrm{Zr}$ phase.

\subsection{Effect of $\mathrm{Zr}$ Content on As-Cast Tensile Properties}

The tensile properties of Al-Fe-Zr alloys with different $\mathrm{Zr}$ contents are listed in Figure 4. According to the tensile data error, the mechanical properties of the alloy with different $\mathrm{Zr}$ contents are relatively stable, the strength error is $\pm 3 \mathrm{MPa}$, and the elongation is within $1 \%$. It can be found that the tensile strength and yield strength gradually increase and the elongation gradually decreases with increasing $\mathrm{Zr}$ content. When the $\mathrm{Zr}$ contents vary from $0.1 \%$ to $0.2 \%$, the tensile strength gradually increases by $22.8 \%$ from 54 to $67 \mathrm{MPa}$ and the yield strength increases gradually by $21.6 \%$ from 51 to $62 \mathrm{MPa}$. However, by further increasing the $\mathrm{Zr}$ content, the strength properties increase, but the increment 
becomes slower. When the $\mathrm{Zr}$ content is $0.4 \%$, the tensile strength and yield strength are 71 and $66 \mathrm{MPa}$, respectively, which are only $6.0 \%$ and $6.4 \%$ higher than that of $\mathrm{Al}-0.35 \mathrm{Fe}-0.2 \mathrm{Zr}$ alloy. The elongation decreases with increasing $\mathrm{Zr}$ content.

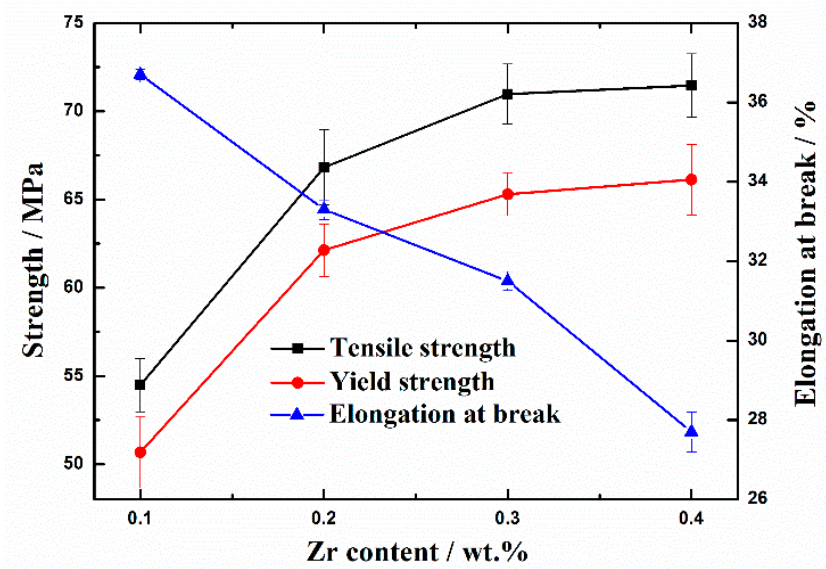

Figure 4. Tensile properties of as-cast Al-Fe-Zr alloy with different $\mathrm{Zr}$ contents.

As can be seen from the tensile fracture morphology in Figure 5, when the Zr content is $0.1 \%$, the ductile fracture is the main fracture, and the fracture is mainly dimple (Figure 5a). When the $\mathrm{Zr}$ content increases to $0.2 \%$ and $0.3 \%$, the dimple becomes significantly shallower indicating that the toughness is gradually decreasing. When the $\mathrm{Zr}$ content reaches $0.4 \%$, the tearing pattern begins to appear around the dimple, indicating that the toughness is the worst at these alloys. This fracture morphology is consistent with the elongation results obtained in Figure 4, which further indicates that the high $\mathrm{Zr}$ content is not conducive to the plasticity improvement.
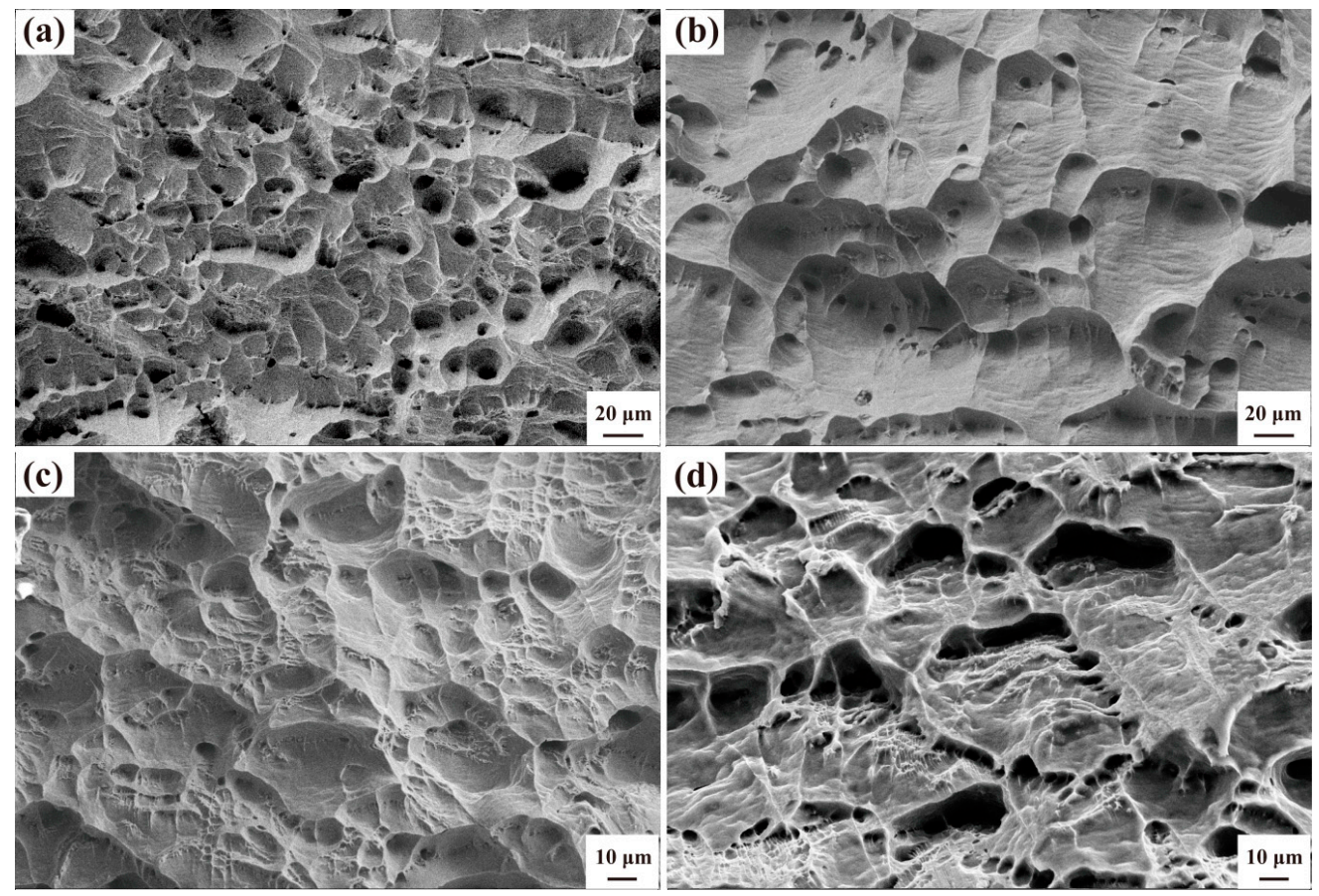

Figure 5. Tensile fracture morphology of as-cast Al-Fe-Zr alloy with different $\mathrm{Zr}$ contents: (a) sdddddddddde0Al-0.35Fe-0.1Zr alloy; (b) Al-0.35Fe-0.2Zr alloy; (c) Al-0.35Fe-0.3Zr alloy; (d) Al-0.35Fe-0.4Zr alloy. 


\section{Discussion}

According to the $\mathrm{Al}-\mathrm{Zr}$ binary phase diagram, the $\mathrm{Zr}$ solutions in the $\mathrm{Al}$ matrix present mainly in the form of interstitial solid solutions by means of equilibrium solidification when the content of $\mathrm{Zr}$ is less than $0.11 \%$. When the $\mathrm{Zr}$ content is above $0.11 \%$, the $\mathrm{Al}_{3} \mathrm{Zr}$ phase is formed during equilibrium solidification [25]. If $\mathrm{Zr}$ exists in the form of the solid solution in Al-0.35Fe- $0.1 \mathrm{Zr}$ alloy, it has the same nucleation effect and can only refine grains by hindering their growth, which limits the refinement effect on the grains. When the $\mathrm{Zr}$ content increases to above $0.2 \%$, the $\mathrm{Al}_{3} \mathrm{Zr}$ appears by a peritectic reaction. The morphology of the $\mathrm{Al}_{3} \mathrm{Zr}$ particles is preferentially characteristic of the L12 structure (metastable) [26,27]. The cubic structure of $\mathrm{Al}_{3} \mathrm{Zr}$ is commensurate with a- $\mathrm{Al}$ (fcc) and acts as an effective heterogeneous nucleant of a-Al during solidification [28]. Therefore, the grain size of $\mathrm{Al}-0.35 \mathrm{Fe}-0.2 \mathrm{Zr}$ alloy is significantly refined compared with that of $\mathrm{Al}-0.35 \mathrm{Fe}-0.2 \mathrm{Zr}$ alloy. With further increasing $\mathrm{Zr}$ content, the number of $\mathrm{Al}_{3} \mathrm{Zr}$ particles increases and the grain refinement effect increases, but the change is minimal.

During solidification, $\mathrm{Zr}$ mainly concentrates in front of the crystal and hinders Fe atom diffusion effectively. Thus, the growth of primary $\mathrm{Al}_{3} \mathrm{Fe}$ is inhibited and a relatively round short rod shape is obtained [29]. With the consumption of Al atoms, the subcooling zone of the components appears in the interface front. The appearance of the component supercooled zone causes the primary $\mathrm{Al}_{3} \mathrm{Fe}$ phase to be wrapped by post-nucleated Fe-rich phases before it grows [30]. In contrast, the appearance of the component supercooled zone also causes dendrite fusion, separation and proliferation of $\mathrm{Al}_{3} \mathrm{Fe}$. Therefore, with increasing $\mathrm{Zr}$ content, the diffusion resistance of $\mathrm{Zr}$ to Fe is enhanced, $\mathrm{Al}_{3} \mathrm{Fe}$ gradually refines and the morphology is gradually formed into clusters composed of shorter rods with smaller sizes [31,32].

The grain size of the as-cast alloys decreases with the increasing of $\mathrm{Zr}$ content. The increment of grain refinement on yield strength $\Delta y$ can be expressed by the Hall-Petch equation $[33,34]$ :

$$
\Delta \mathrm{y}=\mathrm{kd}^{-1 / 2}
$$

where $\mathrm{d}$ is the average grain size and $\mathrm{k}$ is a constant that is $0.04 \mathrm{MPa} \cdot \mathrm{m}^{1 / 2}$ in $\mathrm{Al}$ alloys [35]. The average grain size of the alloys is $76,35,27$ and $23 \mu \mathrm{m}$, respectively. Thus, the increment of grain refinement on yield strength is $4.6,6.8,7.7$ and $8.3 \mathrm{MPa}$, respectively. It is found that strength change caused by fine-grain intensification was significant when the $\mathrm{Zr}$ content was 0.1 to $0.2 \%$. When the $\mathrm{Zr}$ content continues to increase, the strength increment caused by fine-grain intensification changed only marginally.

As a transition element, the concentration of the equilibrium solution of $\mathrm{Fe}$ in the $\mathrm{Al}$ matrix is $0.0058 \%$. Even under the non-equilibrium solidification of metal mold casting, the solution of $\mathrm{Fe}$ in $\mathrm{Al}$ can be negligible [1]. The concentration of the equilibrium solution of $\mathrm{Zr}$ in $\mathrm{Al}$ is $0.11 \%$. Under the same solidification conditions, it can be considered that the $\mathrm{Zr}$ content changes from 0.1 to $0.4 \%$ and the amount of $\mathrm{Zr}$ solution in the alloy is almost unchanged. $\mathrm{Zr}$ atoms in the interstitial solid solution can prevent the movement of dislocation and the slipping of grain boundaries. In contrast, $\mathrm{Zr}$ atoms can lead to lattice distortion of the $\mathrm{Al}$ matrix, which enhances the resistance of dislocation motion and thus increases the strength of the solid solution. The basic rule of solid solution strengthening can be expressed by an equation [36,37]:

$$
\begin{gathered}
\nabla \sigma_{s o l} \propto \varepsilon_{r}^{3 / 2} \sqrt{\mathrm{c}} \\
\varepsilon_{r}=\frac{r-r_{0}}{r_{0}}
\end{gathered}
$$

where $\varepsilon_{r}$ is the lattice misfit, $\mathrm{c}$ is the mole fraction of the solute atom, $r_{0}=0.143 \mathrm{~nm}$ [38], and is the atomic radius of the matrix, and $r=0.216 \mathrm{~nm}$ [39], and is the atomic radius of the solute. It can be seen that when the amount of solid solution is the same, the strengthening effect of the solid solution in the alloys is basically the same. 
Intermetallic compounds possess high hardness and brittleness. They are distributed in the Al matrix, which is equivalent to embedding some irregular hard particles into the soft matrix [40]. Under tension, in order to coordinate deformation, grains in different orientations rotate and this rotation among grains will be hindered by the high hardness phase distributed among grains, resulting in dislocation within grains [25]. As the load continues to increase, the dislocation will start to move. When the dislocation moves to the hard phase interface, it will stop due to the obstruction of the hard phase, thus causing a dislocation plug product at the interface between the hard phase and the matrix. According to the Orowan theory, improvements in yield strength caused by the second relative alloys of $\mathrm{Al}_{3} \mathrm{Zr}$ and $\mathrm{Al}_{3} \mathrm{Fe}$ at the nano or microscale can be calculated by the [41]:

$$
\Delta_{o r}=M \frac{0.4 G b}{\pi \sqrt{1-\gamma}} \frac{\ln \left(\frac{2 r}{b}\right)}{\lambda}
$$

where $M=3.06$ and is the Taylor factor [42], $G=25.4 \mathrm{GPa}$ and is the shear modulus [43], $b=0.2863 \mathrm{~nm}$ and is the magnitude of the Burgers vector [43], $\gamma=0.35$ and is the Poisson ratio of pure $\mathrm{Al}$ [42], $r$ is the mean particle diameter and $\lambda$ is the mean interparticle distance. Therefore, with the increase in $\mathrm{Zr}$ content, the density of $\mathrm{Al}_{3} \mathrm{Zr}$ particles increases and the interparticle distance decreases, resulting in an increase in the increment of yield strength caused by the $\mathrm{Al}_{3} \mathrm{Zr}$ phase.

The plastic deformation of $\mathrm{Al}$ alloys is controlled by dislocation slip [44]. However, the hard $\mathrm{Al}_{3} \mathrm{Fe}$ phase can prevent the movement of dislocation and the slipping of grain boundaries, which lead to the phenomenon of stress focus produced at the $\mathrm{Al}_{3} \mathrm{Fe} / \mathrm{Al}$ matrix interface and inconsistent deformation [30]. As the deformation progresses, the stress concentration and uncoordinated deformation accumulate continuously. After a certain degree of accumulation, the micro-cracks inside the oxide film gradually expand and link, forming cracks around the hard phase, and the further expansion of the cracks causes the alloy to fracture [30]. As for the short rod shape $\mathrm{Al}_{3} \mathrm{Fe}$, the stress concentration effect is serious [31,32]. With the increase in $\mathrm{Zr}$ content, the volume fraction of $\mathrm{Al}_{3} \mathrm{Fe}$ remains unchanged, but the shape of $\mathrm{Al}_{3} \mathrm{Fe}$ changes from a short rod-like form distributed as a discontinuous network to an agglomerated structure consisting of finer and shorter rod-like shapes. The meshed $\mathrm{Al}_{3} \mathrm{Fe}$ is not as good as the cluster-like $\mathrm{Al}_{3} \mathrm{Fe}$ in deformation coordination. The uncoordinated action between $\mathrm{Al}_{3} \mathrm{Fe}$ and the matrix leads to the occurrence and expansion of cracks, which leads to the fracture of the alloy eventually. Therefore, the tensile strength of $\mathrm{Al}-0.35 \mathrm{Fe}-0.1 \mathrm{Zr}$ is less than that of $\mathrm{Al}-0.35 \mathrm{Fe}-0.4 \mathrm{Zr}$. As the number of strengthening phases increases, the elongation of alloys decreases gradually.

\section{Conclusions}

The microstructure of as-cast $\mathrm{Al}-\mathrm{Fe}-\mathrm{Zr}$ alloys changes as a function of the $\mathrm{Zr}$ content. When the $\mathrm{Zr}$ content is $0.1 \%$, the alloy is composed of the $\mathrm{Al}_{3} \mathrm{Fe}$ phase and distributing in the $\mathrm{Al}$ matrix, and the $\mathrm{Zr}$ element exists in the solid-solution state. As the content of $\mathrm{Zr}$ continues to increase, nanosized $\mathrm{Al}_{3} \mathrm{Zr}$ particles appear in the alloy.

$\mathrm{Zr}$ addition in the $\mathrm{Al}-0.35 \mathrm{Fe}$ alloy refines the microstructure of the as-cast alloy and improves the morphology of the $\mathrm{Al}_{3} \mathrm{Fe}$ phase. As the $\mathrm{Zr}$ content increases from 0.1 to $0.4 \%$, the grain size of the $\mathrm{Al}$ matrix decreases from 76 to $23 \mu \mathrm{m}$. The morphology of the eutectic $\mathrm{Al}_{3} \mathrm{Fe}$ phase changed from a short rod-like shape to an agglomerated structure consisting of finer and shorter rod-like shapes.

The tensile and yield strengths increase with increasing $\mathrm{Zr}$ content. When the $\mathrm{Zr}$ content increased from 0.1 to $0.4 \%$, the tensile strength gradually increases from 54 to $71 \mathrm{MPa}$ and the yield strength gradually increases from 51 to $66 \mathrm{MPa}$. The strengthening mechanism of the alloy can be attributed to the combination of fine-grain, solution and second-phase strengthening.

Author Contributions: R.G. and H.Z. conceived and designed the experiments, J.Y., C.H. and K.X. performed the experiments and analyzed the data, J.Y. wrote the paper. All authors have read and agreed to the published version of the manuscript. 
Funding: This research was funded by National key research and development program, grant number 2018YFB2001800, the National Natural Science Foundation of China, grant numbers 51871184, High-Level Talent Support Program of Liaoning, grant number XLYC1802128 and Liaoning Province Ministry of Education Scientific Study Project, grant number LQ2019002.

Conflicts of Interest: The authors declare no conflict of interest.

\section{References}

1. Liang, D.; Korgul, P.; Jones, H. Composition and solidification microstructure selection in the interdendritic matrix between primary Al3Fe dendrites in hypereutectic AlFe alloys. Acta Mater. 1996, 44, 2999-3004. [CrossRef]

2. Chen, J.; Lengsdorf, R.; Henein, H.; Herlach, D.M.; Dahlborg, U.; Calvo-Dahlborg, M. Microstructure evolution in undercooled $\mathrm{Al}-8 \mathrm{wt} \% \mathrm{Fe}$ melts: Comparison between terrestrial and parabolic flight conditions. J. Alloy. Compd. 2013, 556, 243-251. [CrossRef]

3. Shuai, G.; Li, Z.; Zhang, D.; Tong, Y.; Li, L. The mechanical property and electrical conductivity evolution of Al-Fe alloy between room temperature and elevated temperature ECAP. Vacuum 2020, 109813. [CrossRef]

4. Jiang, H.; Li, S.; Zheng, Q.; Zhang, L.; He, J.; Song, Y.; Deng, C.; Zhao, J. Effect of minor lanthanum on the microstructures, tensile and electrical properties of Al-Fe alloys. Mater. Des. 2020, 195, 108991. [CrossRef]

5. Chankitmunkong, S.; Eskin, D.G.; Limmaneevichitr, C. Structure refinement, mechanical properties and feasibility of deformation of hypereutectic Al-Fe-Zr and $\mathrm{Al}-\mathrm{Ni}-\mathrm{Zr}$ alloys subjected to ultrasonic melt processing. Mater. Sci. Eng. A 2020, 788, 139567. [CrossRef]

6. Lin, B.; Zhang, W.; Zheng, X.; Zhao, Y.; Lou, Z.; Zhang, W. Developing high performance mechanical properties at elevated temperature in squeeze cast Al-Cu-Mn-Fe-Ni alloys. Mater. Charact. 2019, 150, $128-137$. [CrossRef]

7. Zhao, Q.; Qian, Z.; Cui, X.; Wu, Y.; Liu, X. Optimizing microstructures of dilute Al-Fe-Si alloys designed with enhanced electrical conductivity and tensile strength. J. Alloy. Compd. 2015, 650, 768-776. [CrossRef]

8. Shi, Z.; Gao, K.; Shi, Y.; Wang, Y. Microstructure and mechanical properties of rare-earth-modified Al-1Fe binary alloys. Mater. Sci. Eng. A 2015, 632, 62-71. [CrossRef]

9. Zhu, X.; Blake, P.; Dou, K.; Ji, S. Strengthening die-cast Al-Mg and Al-Mg-Mn alloys with Fe as a beneficial element. Mater. Sci. Eng. A 2018, 732, 240-250. [CrossRef]

10. Zhao, Y.; Du, W.; Koe, B.; Connolley, T.; Irvine, S.; Allan, P.K.; Schlepütz, C.M.; Zhang, W.; Wang, F.; Eskin, D.G.; et al. 3D characterisation of the Fe-rich intermetallic phases in recycled Al alloys by synchrotron X-ray microtomography and skeletonization. Scr. Mater. 2018, 146, 321-326. [CrossRef]

11. Wang, X.; Guan, R.; Misra, R.; Wang, Y.; Li, H.; Shang, Y. The mechanistic contribution of nanosized Al3Fe phase on the mechanical properties of Al-Fe alloy. Mater. Sci. Eng. A 2018, 724, 452-460. [CrossRef]

12. Stolyarov, V.; Lapovok, R.; Brodova, I.G.; Thomson, P. Ultrafine-grained Al-5 wt.\% Fe alloy processed by ECAP with backpressure. Mater. Sci. Eng. A 2003, 357, 159-167. [CrossRef]

13. Li, L.; Zhang, Y.; Esling, C.; Jiang, H.; Zhao, Z.; Zuo, Y.; Cui, J. Influence of a high magnetic field on the precipitation behavior of the primary Al3Fe phase during the solidification of a hypereutectic Al-3.31wt $\% \mathrm{Fe}$ alloy. J. Cryst. Growth 2012, 339, 61-69. [CrossRef]

14. John, R.; Karati, A.; Joseph, J.; Fabijanic, D.; Murty, B. Microstructure and mechanical properties of a high entropy alloy with a eutectic composition (AlCoCrFeNi2.1) synthesized by mechanical alloying and spark plasma sintering. J. Alloy. Compd. 2020, 835, 155424. [CrossRef]

15. Zhang, J.; Jiang, X.; Ma, M.; Jiang, B.; Wang, B.; Yi, D. Effect of scandium micro-alloying on the creep resistance properties of Al-0.7Fe alloy cables. Mater. Sci. Eng. A 2017, 699, 194-200. [CrossRef]

16. Wang, Y.; Li, Z.; Yu, T.; Medjahed, A.; Wu, R.; Hou, L.; Zhang, J. Effect of Sc and Zr on Microstructure and Mechanical Properties of As-Cast Al-Li-Cu Alloys. Adv. Eng. Mater. 2017, 20, 1700898. [CrossRef]

17. Deng, Y.; Yin, Z.; Zhao, K.; Duan, J.; He, Z. Effects of Sc and Zr microalloying additions on the microstructure and mechanical properties of new Al-Zn-Mg alloys. J. Alloy. Compd. 2012, 530, 71-80. [CrossRef]

18. Pan, S.; Chen, X.; Zhou, X.; Wang, Z.; Chen, K.; Cao, Y.; Lu, F.; Li, S. Micro-alloying effect of Er and Zr on microstructural evolution and yield strength of Al-3Cu (wt.\%) binary alloys. Mater. Sci. Eng. A 2020, 790, 139391. [CrossRef] 
19. Poplawsky, J.D.; Milligan, B.K.; Allard, L.F.; Shin, D.; Shyam, A. The synergistic role of Mn and Zr/Ti in producing $\theta^{\prime} / \mathrm{L} 12$ co-precipitates in Al-Cu alloys. Acta Mater. 2020, 194, 577-586. [CrossRef]

20. Xiao, Q.; Xu, Y.; Huang, J.; Li, B.; Wang, B.; Liu, S.; Fu, L. Effects of quenching agents, two-step aging and microalloying on tensile properties and stress corrosion cracking of Al-Zn-Mg-Cu alloys. J. Mater. Res. Technol. 2020, 9, 10198-10208. [CrossRef]

21. Ye, J.; Guan, R.; Zhao, H.; Yin, A. Effect of Zr content on the precipitation and dynamic softening behavior in Al-Fe-Zr alloys. Mater. Charact. 2020, 162, 110181. [CrossRef]

22. Goulart, P.R.; Lazarine, V.B.; Leal, C.V.; Spinelli, J.E.; Cheung, N.; Garcia, A. Investigation of intermetallics in hypoeutectic Al-Fe alloys by dissolution of the Al matrix. Intermetallics 2009, 17, 753-761. [CrossRef]

23. Yu, J.; Wanderka, N.; Miehe, G.; Banhart, J. Intermetallic phases in high purity Al-10Si-0.3Fe cast alloys with and without Sr modification studied by FIB tomography and TEM. Intermetallics 2016, 72, 53-61. [CrossRef]

24. Wang, X.; Guan, R.G.; Li, Y.D.; Chen, T.J. Comparison of contribution of sub-rapid cooling and shear deformation to refinement of Fe-rich phase in hypereutectic Al-Fe alloy during rheo-extrusion. J. Iron Steel Res. Int. 2020, 1-9.

25. Mondolfo, L.F. Aluminum Alloys: Structure and Properties; Elsevier: London, UK, 1988; pp. 51-353.

26. Ohashi, T.; Ichikawa, R. Grain Refinement in Aluminium-Zirconium and Aluminium-Titanium Alloys by Metastable Phases. Mat. Res. Adv. Tech. 1973, 64, 517-521.

27. Mikhaylovskaya, A.; Mochugovskiy, A.; Levchenko, V.; Tabachkova, N.; Mufalo, W.; Portnoy, V. Precipitation behavior of L12 Al3Zr phase in Al-Mg-Zr alloy. Mater. Charact. 2018, 139, 30-37. [CrossRef]

28. Knipling, K.E.; Karnesky, R.A.; Lee, C.P.; Dunand, D.C.; Seidman, D.N. Precipitation evolution in Al-0.1Sc, $\mathrm{Al}-0.1 \mathrm{Zr}$ and $\mathrm{Al}-0.1 \mathrm{Sc}-0.1 \mathrm{Zr}$ (at.\%) alloys during isochronal aging. Acta Mater. 2010, 58, 5184-5195. [CrossRef]

29. Belov, N.; Alabin, A.; Matveeva, I.; Eskin, D. Effect of Zr additions and annealing temperature on electrical conductivity and hardness of hot rolled Al sheets. Trans. Nonferrous Met. Soc. China 2015, 25, 2817-2826. [CrossRef]

30. Chang, L.; Tang, H.; Guo, J. Strengthening effect of nano and micro-sized precipitates in the hot-extruded Mg-5Sn-3Zn alloys with Ca addition. J. Alloy. Compd. 2017, 703, 552-559. [CrossRef]

31. Karaköse, E.; Keskin, M. Structural investigations of mechanical properties of Al based rapidly solidified alloys. Mater. Des. 2011, 32, 4970-4979. [CrossRef]

32. Kilicaslan, M.F. Effect of $\mathrm{V}$ addition on the nano-size spherical particles growing on the Fe-bearing intermetallics and silicon phases of gas atomized hypereutectic Al-20Si-5Fe alloys. J. Alloy. Compd. 2014, 606, 86-91. [CrossRef]

33. Hall, E.O. The Deformation and Ageing of Mild Steel: III Discussion of Results. Proc. Phys. Soc. Sect. B 1951, 64, 747-753. [CrossRef]

34. Petch, N.J. The cleavage strengh of polycrystals. J. Iron. Steel. Inst. 1953, 174, 25-28.

35. Nes, E.; Holmedal, B.; Evangelista, E.; Marthinsen, K. Modelling grain boundary strengthening in ultra-fine grained aluminum alloys. Mater. Sci. Eng. A 2005, 410, 178-182. [CrossRef]

36. Nabarro, F.R.N.; Mura, T. Dislocations in Solids: Dislocations in Metallurgy (Vol. 4). J. Appl. Mech. 1981, 48, 451-452. [CrossRef]

37. Jiang, D.M.; Cao, Z.Y.; Guo, L.; Sun, X.; Zhang, J.L. Microstructure and Corrosion Properties of Mg-Zn-Ca-Nd Alloy for Biomedical Application. Adv. Mat. Res. 2013, 750, 756-759. [CrossRef]

38. Dang, J.-Z.; Huang, Y.-F.; Cheng, J. Effect of Sc and Zr on microstructures and mechanical properties of as-cast Al-Mg-Si-Mn alloys. Trans. Nonferrous Met. Soc. China 2009, 19, 540-544. [CrossRef]

39. Liu, Y.; Chong, X.; Jiang, Y.-H.; Zhou, R.; Feng, J. Mechanical properties and electronic structures of Fe-Al intermetallic. Phys. B Condens. Matter 2017, 506, 1-11. [CrossRef]

40. Askeland, D.R.; Phule, P.P. The Science and Engineering of Materials; Cengage Learning: Boston, MA, USA, 2003; pp. 360-374.

41. Kelly, A.; Nicholson, R.B. Strengthening Methods in Crystals; Elsevier: New York, NY, USA, 1971; pp. 74-85.

42. Meyers, M.A.; Chawla, K.K. Mechanical Metallurgy: Principles and Applications; Prentice-Hall Ltd.: Englewood Cliffs, NJ, USA, 1984; pp. 102-115. 
43. Frost, H.J.; Ashby, M.F. Deformation Mechanism Maps: The Plasticity and Creep of Metals and Ceramics; Pergamon Press Ltd.: Oxford, UK, 1982; pp. 224-235.

44. Zhang, P.; Li, Z.M.; Liu, B.L.; Ding, W.J. Tensile properties and deformation behaviors of anew aluminum alloy for high pressure die casting. J. Mater. Sci Technol 2017, 33, 367-378. [CrossRef]

Publisher's Note: MDPI stays neutral with regard to jurisdictional claims in published maps and institutional affiliations.

(C) 2020 by the authors. Licensee MDPI, Basel, Switzerland. This article is an open access article distributed under the terms and conditions of the Creative Commons Attribution (CC BY) license (http://creativecommons.org/licenses/by/4.0/). 